\title{
DETERMINAN KEMAMPUAN LABA PADA BADAN LAYANAN UMUM DAERAH (BLUD) PUSKESMAS KECAMATAN PEMERINTAH PROVINSI DKI JAKARTA TAHUN 2016
}

\author{
Dewi Cahyani Pangestuti \\ Program Studi Manajemen, Fakultas Ekonomi \& Bisnis, UPN” “Veteran" Jakarta \\ Email : dewichepe@upnvj.ac.id
}

\begin{abstract}
ABSTRAK
Puskesmas yang pada prinsipnya sama dengan unit pemerintah, atau agen sosial yang didirikan dan dioperasikan dengan motif sosial atau tidak mengharapkan laba. Standar keberhasilan suatu puskesmas dinilai dari kualitas pelayanan yang mereka berikan. Puskesmas sebagai salah satu lembaga yang memberikan pelayanan kesehatan pada masyarakat bisa bertindak sebagai Badan Penyelenggara sekaligus Pemberi Pelayanan Kesehatan. Tujuan penelitian ini adalah untuk mengetahui dan menganalisis pengaruh variabel likuiditas, tingkat utang dan efisiensi modal kerja baik secara parsial maupun secara simultan terhadap kemampuan laba pada Badan Layanan Umum Daerah Puskesmas Pemerintah Provinsi DKI Jakarta. Dari seluruh populasi yaitu 49 Puskesmas Kecamatan Pemerintah Provinsi DKI Jakarta, yang dapat menjadi sampel dalam penelitian ini sebanyak 37 Puskesmas, yang melaporkan neraca dan laporan realisasi anggaran secara lengkap (meliputi semua variabel yang digunakan dalam penelitian ini) sedangkan 12 Puskesmas lainnya tidak dapat menjadi sampel dalam penelitian ini karena tidak memenuhi persyaratan (tidak melaporkan neraca dan laporan realisasi anggaran secara lengkap). Dari analisis terhadap hasil penelitian pengaruh Current Ratio, Debt to Total Asset, dan Efisiensi Modal Kerja terhadap Kemampuan Laba Puskesmas Pemerintah DKI Jakarta, dapat disimpulkan bahwa berdasarkan uji $\mathrm{t}$ dan uji $\mathrm{F}$ ketiga variabel independen yang dianalisis yaitu Likuiditas (Current Ratio), Tingkat Utang (Debt to Total Asset), Efisiensi Modal Kerja baik secara parsial maupun simultan berpengaruh signifikan terhadap Kemampuan Laba. Besarnya Adjusted $\mathrm{R}^{2}$ sebesar $44.1 \%$, artinya pengaruh ketiga variabel independent sebesar 44,1\%, dan sisanya 55,9\% dipengaruhi oleh faktor lain di luar model.
\end{abstract}

Kata Kunci: Likuiditas, Tingkat Utang, Efisiensi Modal Kerja, Kemampuan Laba, Puskesmas Kecamatan Pemerintah Provinsi DKI

\section{PENDAHULUAN}

Puskesmas sebagai organisasi non profit oriented sangat memerlukan informasi biaya. Tanpa informasi biaya, pihak manajemen tidak memiliki ukuran apakah masukan yang dikorbankan memiliki nilai ekonomis yang lebih rendah dari pada nilai keluarannya, sehingga manajemen tidak memiliki informasi apakah kegiatan usahanya menghasilkan sisa hasil usaha atau tidak. Sisa hasil usaha ini sangat diperlukan untuk mengembangkan dan mempertahankan eksistensi puskesmas. Begitu juga tanpa informasi biaya, manajemen tidak memiliki dasar untuk mengalokasikan berbagai sumber ekonomi yang dikorbankan dalam menghasilkan sumber ekonomi yang lain.

Kemampuan laba tidak terlepas dari faktor likuiditas, tingkat hutang dan efisiensi modal kerja, Wibowo dan Wartini (2012). Tingkat likuiditas merupakan salah satu faktor yang sangat penting dan memerlukan perhatian khusus dalam penanganannya, karena tingkat likuiditas mencerminkan kemungkinan kemampuan dalam memenuhi kewajiban-kewajiban jangka pendek, Riyanto (2013). Dalam pengukuran tingkat likuiditas diperlukan norma-norma untuk mengukur keadaan tingkat likuiditas tersebut. Dalam kenyataannya pengendalian anggaran kas tidak jarang menimbulkan masalah-masalah seperti adanya likuiditas yang berlebihan (Over Liquid) dan likuiditas yang rendah (Under Liquid), Putri (2009). Pengelolaan likuiditas dalam menghadapi kondisi Over Liquid maupun Under Liquid pada tiap-tiap organisasipun berbeda - beda. Pada 
puskesmas, pihak manajemen puskesmas akan dihadapkan pada keputusan yang mengakibatkan adanya pertukaran (trade off) antara faktor likuiditas dan kemampuan laba. Keputusan untuk menekan agar tingkat likuiditas terjaga, kemungkinan dapat mempengaruhi kemampuan laba puskesmas. Sebaliknya, keputusan yang cenderung memaksimalkan kemampuan laba puskesmas, kemungkinan dapat mempengaruhi tingkat likuiditas puskesmas.

Disamping keputusan di atas, pihak manajemen Puskesmas juga dihadapkan pada keputusan dibidang keuangan lainnya yaitu sumber dana. Penggunaan hutang akan menentukan tingkat hutang / leverage puskesmas. Dengan menggunakan lebih banyak hutang dibandingkan dengan modal sendiri, maka beban tetap yang ditanggung puskesmas tinggi, yang pada akhirnya dapat menyebabkan kemampuan laba puskesmas akan turun, Djarwanto, (2011). Tingkat hutang merupakan kemampuan perusahaan untuk melunasi kewajibannya. Rasio ini digunakan untuk mengukur kemampuan puskesmas untuk membayar seluruh kewajibannya, baik jangka pendek maupun jangka panjang. Dari uraian tersebut, maka jelas bahwa tingkat hutang akan mempengaruhi kemampuan puskesmas dalam menghasilkan keuntungan.

Manajemen modal kerja adalah kegiatan yang mencakup semua fungsi manajemen atas aktiva lancar dan kewajiban jangka pendek perusahaan, Guna, dan Herawaty (2010). Efisiensi modal kerja adalah ketepatan cara (usaha dan kerja) dalam menjalankan sesuatu yang tidak membuang waktu, tenaga, biaya dan kegunaan berkaitan penggunaan modal kerja yaitu mengupayakan agar modal kerja yang tersedia tidak kelebihan dan tidak juga kekurangan, Widiyanti, et al (2014). Pengelolaan modal kerja berkaitan dengan kebijakan penentuan berapa besarnya jumlah aktiva lancar yang dibutuhkan dan bagaimana cara pendanaannya. Keputusan mengenai jumlah aktiva lancar ini tidak terlepas dari sisi likuiditas yang harus dijaga, batas kemampuan aktiva lancar dalam melayani kegiatan puskesmas sehari - hari yang ditunjukkan oleh tingkat perputaran modal kerja, komposisi komponen masing - masing aktiva lancar (kas, piutang dan perseediaan). Sedangkan keputusan mengenai cara pendanaannya menyangkut falsafah pengelolaannya yaitu kutub mana kebijaksanaan modal kerja dapat dijalankan.

Pihak manajemen puskesmas harus memperhatikan pengelolaan modal kerjanya secara efisien tanpa mengurangi kemampuan kegiatan operasinya dalam mendapatkan laba. Efisiensi pengelolaan modal kerja dapat dilihat dari perputaran modal kerja. Semakin tinggi perputaran modal kerja maka puskesmas semakin efisien, yang pada akhirnya rentabilitas semakin tinggi, Ahmad (2013).

Nugraeni (2005), melakukan penelitian tentang analisis pengaruh efisiensi modal kerja, likuiditas, dan solvabilitas terhadap profitabilitas pada perusahaan property dan real estate yang go publik dibursa efek Jakarta pada tahun 1998-2002. Rasio-rasio yang digunakan adalah rasio working capital turnover, current ratio, debt to equity ratio dan return on investment. Adapun sampel dalam penelitiannya adalah semua perusahaan property dan real estate yang terdaftar di BEJ, yaitu sebanyak 30 perusahaan. Penelitian Nugraeni (2005), menggunakan analisis regresi linier berganda, yang hasilnya menunjukkan bahwa secara parsial hanya variabel efisiensi modal kerja dan solvabilitas yang mempunyai pengaruh terhadap profitabilitas, sedangkan variabel likuiditas tidak mempunyai pengaruh terhadap profitabilitas. Secara simultan semua variabel berpengaruh signifikan terhadap profitabilitas. Asih (2009) dan Raheman et al. (2009), melakukan penelitian mengenai pengaruh perputaran modal kerja, likuiditas dan solvabilitas terhadap profitabilitas pada perusahaan Real Estate dan property di BEI. Rasio yang digunakan antara lain likuiditas 
menggunakan rasio current ratio, tingkat hutang menggunakan rasio dept to total asset, efisiensi modal kerja menggunakan rasio working capital turnover.

Dari uraian diatas terdapat reseach gap mengenai hasil penelitian yang diperoleh Nugraeni (2005); Asih (2009); Raheman et al. (2009), dimana menurut Nugraeni (2005) dan Raheman (2009), variabel efisiensi modal kerja dan solvabilitas berpengaruh signifikan terhadap profitabilitas sedangkan likuiditas tidak berpengaruh, namun hasil penelitiannya dibantah oleh Asih yang menyatakan bahwa likuiditas dan solvabilitas berpengaruh terhadap profitabilitas sedangkan efisiensi modal kerja tidak berpengaruh. Namun dari hasil penelitian Nugraeni (2005) dan Asih (2009), juga terdapat kesamaan hasil yaitu secara simultan variabel efisiensi modal kerja, likuiditas, dan solvabilitas berpengaruh signifikan terhadap profitabilitas perusahaan. Karena adanya research gap inilah peneliti mencoba untuk melakukan penelitian kembali mengenai pengaruh efisiensi modal kerja, likuiditas, dan solvabilitas terhadap profitabilitas, namun peneliti mengganti obyek penelitian dengan BLUD Puskesmas di Provinsi DKI Jakarta.

Dari semua uraian di atas, maka dapat dikatakan bahwa likuiditas, tingkat hutang dan efisiensi modal kerja dapat mempengaruhi kemampuan laba. Oleh sebab itu apabila ketiga hal tersebut diperhatikan dan dikelola dengan benar oleh pihak manajemen puskesmas, maka dimungkinkan dapat meningkatkan kemampuan labanya. Beberapa gambaran likuiditas, tingkat hutang, efisiensi modal kerja dan kemampuan laba puskesmas di Provinsi DKI Jakarta.

Tabel 1. Rata - Rata Tingkat Likuiditas, Tingkat Hutang, Efisiensi Modal Kerja dan Kemampuan Laba BLUD Puskesmas di Provinsi DKI Jakarta Tahun 2016

\begin{tabular}{|c|c|c|c|}
\hline $\begin{array}{c}\text { KEMAMPUAN } \\
\text { LABA }\end{array}$ & $\begin{array}{c}\text { CURRENT } \\
\text { RATIO }\end{array}$ & $\begin{array}{c}\text { DEBT TO } \\
\text { TOTAL ASSET }\end{array}$ & $\begin{array}{c}\text { EFISIENSI MODAL } \\
\text { KERJA }\end{array}$ \\
\hline-87.67 & 104544.88 & 0.17 & 17.73 \\
\hline
\end{tabular}

Dari tabel 1. di atas, dapat dilihat bahwa pada tahun 2016 kemampuan laba BLUD Puskesmas di Pemerintah Provinsi DKI Jakarta menunjukkan angka minus yaitu -87.67, hal ini menggambarkan bahwa Puskesmas belum mampu untuk menghasilkan laba, malah cenderung rugi, karena pendapatan yang diperoleh dari usahanya lebih kecil dari pada biaya yang dikeluarkan. Dengan kata lain Puskesmas belum mampu untuk menutupi cost recovery rate yaitu nilai dalam persen yang menunjukkan seberapa besar kemampuan Puskesmas menutup biayanya dengan penerimaannya dari retribusi pasien (Revenue), hal ini terjadi kemungkinan karena sifat dari puskesmas yang merupakan pelayanan kesehatan yang mengutamakan upaya penyembuhan dan pemulihan pasien.

Sedangkan untuk likuiditas, dilihat dari current ratio cukup tinggi yaitu 104544.88, hal ini menunjukkan bahwa Puskesmas mampu untuk memenuhi kewajiban keuangannya yang harus segera dipenuhi, atau Puskesmas mampu untuk memenuhi kewajiban keuangan jangka pendeknya. Berdasarkan debt to total asset rata - rata Puskesmas Pemerintah Provinsi DKI Jakarta yaitu sebesar 0.17, angka ini menunjukkan bahwa Puskesmas dapat menutupi hutangnya dengan aktiva yang dimiliki. Angka ini cukup kecil, hal ini kemungkinan dikarenakan Puskesmas tidak memiliki 
hutang yang besar kepada pihak lain. Sedangkan angka efisiensi modal kerja sebesar 17.73, hal ini menunjukkan bahwa Puskesmas cukup efisien menggunakan modal kerjanya, atau aktiva yang dimiliki Puskesmas mampu untuk menutupi hutang - hutangnya.

Dari pengamatan penulis, beberapa permasalahan yang dihadapi oleh puskesmas di Provinsi DKI Jakarta, antara lain : a. Puskesmas belum mampu untuk menghasilkan laba. b. Puskesmas belum belum mampu menutupi cost recovery rate. c. Likuiditas Puskesmas cukup tinggi, sehingga dana tidak berputar dan tidak mampu untuk menghasilkan laba yang tinggi. d. Tingkat hutang Puskesmas sangat rendah, padahal dengan manajemen pengelolaan hutang yang baik justru dapat sebagai pengungkit laba Puskesmas. e. Efisiensi modal kerja Puskesmas cukup rendah, perlu pengawasan terhadap sumber dan penggunaan modal kerja.

Tujuan dari penelitian ini adalah untuk mendiskripsikan dan menganalisis pengaruh likuiditas, tingkat hutang dan efisiensi modal kerja terhadap kemampuan laba pada Badan Layanan Umum Daerah Puskesmas Kecamatan Pemerintah Provinsi DKI Jakarta. Adapun kontribusi penelitian ini adalah memberikan kontribusi pemikiran terhadap para pemakai laporan keuangan dalam memahami bagaimana pengaruh likuiditas, tingkat utang dan efisiensi modal kerja terhadap kemampuan laba dan menambah pengetahuan pihak pimpinan sehingga diharapkan membantu pihak pimpinan dalam pengelolaan anggaran.

\section{METODE PENELITIAN}

Dari seluruh populasi yaitu 49 Puskesmas Kecamatan Pemerintah Provinsi DKI Jakarta, yang dapat menjadi sampel dalam penelitian ini sebanyak 37 Puskesmas, yang melaporkan neraca dan laporan realisasi anggaran secara lengkap (meliputi semua variabel yang digunakan dalam penelitian ini) sedangkan 12 Puskesmas lainnya tidak dapat menjadi sampel dalam penelitian ini karena tidak memenuhi persyaratan (tidak melaporkan neraca dan laporan realisasi anggaran secara lengkap).

Teknik analisis yang digunakan adalah analisis regresi berganda. Analisis regresi ini dapat digunakan untuk memperoleh gambaran yang menyeluruh mengenai hubungan antara variabel dependen dan independen secara menyeluruh baik secara simultan atau secara parsial. Sebelum melakukan uji regresi linier berganda, metode ini mensyaratkan untuk melakukan uji asumsi klasik guna mendapatkan hasil terbaik.

a. Uji Persyaratan Analisis

1) Uji Normalitas

2) Uji Multikolinieritas

3) Uji Heteroskedastisitas

4) Uji Autokorelasi

b Regresi Linier Berganda

c. Uji Hipotesis

1) Uji t (individual test) dilakukan untuk mengukur signifikansi koefisien variabel bebas dengan variabel terikat secara parsial.

2) Uji $\mathrm{F}$ ditujukan untuk menguji tingkat pengaruh semua variabel independent secara bersama-sama terhadap variabel dependent.

Model penelitian dapat dilihat pada gambar 1. 


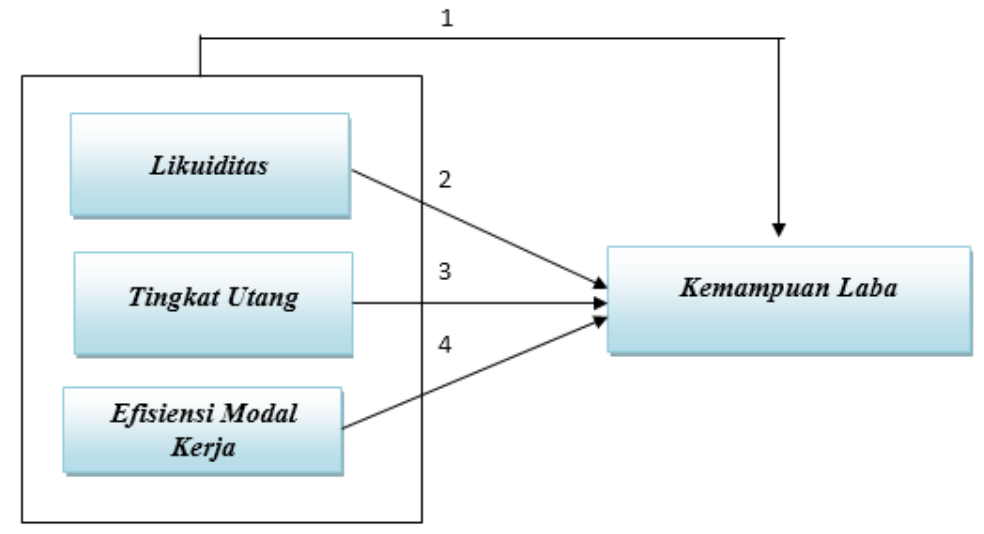

Gambar 1. Kerangka Pemikiran

Untuk memudahkan pengukuran suatu variabel penelitian maka perlu dirumuskan terlebih dahulu, sehingga pada pengukurannya nanti tergantung pada baik tidaknya konsep operasional yang disusun.

a. Likuiditas adalah rasio yang bertujuan untuk mengukur kemampuan suatu perusahaan untuk memenuhi kewajiban jangka pendeknya dengan aktiva lancarnya, yang dalam penelitian ini menggunakan Current Ratio, yaitu rasio yang menunjukkan kemampuan aktiva lancar yang dimiliki dalam membayar kewajiban jangka pendek, semakin tinggi rasio semakin baik.

Current Ratio $=\frac{\text { Aktiva Lancar }}{\text { Utang Lancar }}$

b. Tingkat utang adalah merupakan rasio yang memperlihatkan proposi antara kewajiban yang dimiliki dan seluruh kekayaan yang dimiliki. Dalam penelitian ini, menggunakan Debt to total Asset, yaitu merupakan perbandingan antara total utang dengan total aktiva.

Debt to Total Asset $=\frac{\text { Total Utang }}{\text { Total Aktiva }}$

c. Efisiensi Modal kerja adalah rasio yang menunjukkan kemampuan dana yang tertanam dalam keseluruhan aktiva berputar dalam satu periode tertentu. Metode analisis ini digunakan untuk melihat bagaimana perputaran modal kerja perusahaan dalam kurun waktu tertentu. Rasio yang digunakan yaitu Net Working Capital to Total Asset yaitu dengan membandingkan antara modal kerja dengan total asset :

Modal Kerja Bersih = Aktiva Lancar - Utang Lancar

Efisiensi modal kerja $=\frac{\text { Modal kerja bersih }}{\text { Total Asset }}$

4) Kemampuan Laba adalah pendapatan operasional plus bunga dikurangi dengan biaya operasional dibagi dengan pendapatan operasional plus bunga. Kemampuan laba dirumuskan sebagai berikut :

Kemampuan Laba $=\frac{\text { pendapatan operasional }+ \text { bunga }- \text { biaya operasional }}{\text { biaya operasional }+ \text { bunga }}$ 
Adapun hasil ringkasan dari definisi tersebut di atas adalah sebagai berikut :

\section{Tabel 2. Ringkasan Variabel Penelitian}

\begin{tabular}{|c|c|c|c|}
\hline Variabel & Definisi Operasional & Indikator Pengukuran & Skala \\
\hline $\begin{array}{l}\text { Likuiditas } \\
\text { (X1) }\end{array}$ & $\begin{array}{l}\text { rasio yang bertujuan untuk } \\
\text { mengukur kemampuan suatu } \\
\text { perusahaan untuk memenuhi } \\
\text { kewajiban jangka pendeknya } \\
\text { dengan aktiva lancarnya }\end{array}$ & Current Ratio $=\frac{\text { Aktiva Lancar }}{\text { Utang Lancar }}$ & Rasio \\
\hline $\begin{array}{l}\text { Tingkat utang } \\
\text { (X2) }\end{array}$ & $\begin{array}{l}\text { rasio yang memperlihatkan } \\
\text { proposi antara kewajiban yang } \\
\text { dimiliki dan seluruh kekayaan } \\
\text { yang dimiliki. }\end{array}$ & Debt to Total Asset $=\frac{\text { Total Utang }}{\text { Total Aktiva }}$ & Rasio \\
\hline $\begin{array}{l}\text { Efisiensi Modal } \\
\text { Kerja (Х3) }\end{array}$ & $\begin{array}{l}\text { rasio yang menunjukkan } \\
\text { kemampuan dana yang tertanam } \\
\text { dalam keseluruhan } \\
\text { berputar dalam satu periode } \\
\text { tertentu. }\end{array}$ & $\begin{array}{l}\text { Efisiensi Modal kerja } \\
\qquad=\frac{\text { Modal Kerja bersih }}{\text { Total Asset }}\end{array}$ & Rasio \\
\hline $\begin{array}{l}\text { Kemampuan } \\
\operatorname{Laba}(Y)\end{array}$ & $\begin{array}{l}\text { Kemampuan peruashaan untuk } \\
\text { memperoleh laba dan potensi } \\
\text { untuk memperoleh penghasilan } \\
\text { pada masa yang akan datang }\end{array}$ & $\begin{array}{l}\text { Kemampuan laba } \\
=\frac{\text { pendapatan ops }+ \text { bunga }- \text { biaya ops }}{\text { biaya ops }+ \text { bunga }}\end{array}$ & Rasio \\
\hline
\end{tabular}

Sumber : hasil pengolahan data

\section{HASIL DAN PEMBAHASAN}

1. Uji Asumsi Klasik

a. Uji Normalitas

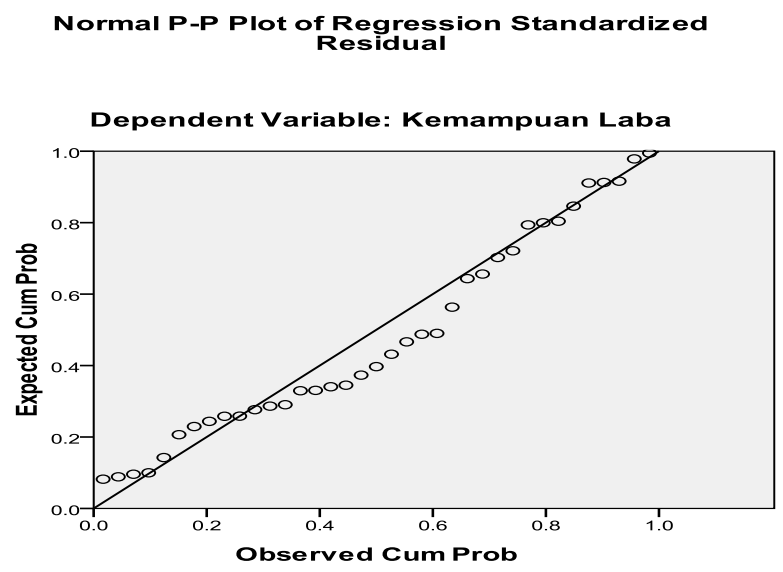

Gambar 2. Grafik P-P Plot

Dari gambar di atas terlihat bahwa data (titik-titik) menyebar di sekitar garis diagonal serta penyebarannya mengikuti garis diagonal yang berarti bahwa model regresi layak digunakan 
untuk memprediksi variabel Kemampuan Laba berdasarkan masukkan variabel Likuiditas (Current Ratio), Tingkat Hutang (Debt to Total Asset), Efisiensi Modal Kerja.

b. Uji Multikolineritas

Tabel 3. Collinearity Statistics

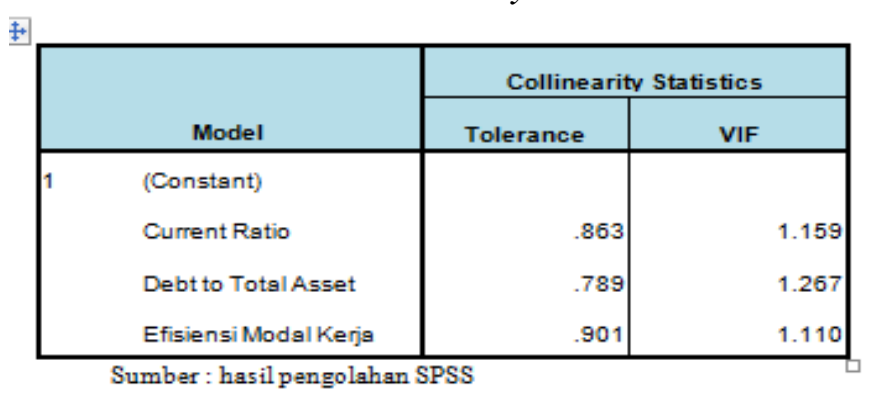

Dari tabel di atas, menunjukkan besarnya nilai :

1) Variabel Likuiditas (Current Ratio) nilai VIF $=1.159$

2) Variabel Tingkat Hutang (Debt to Total Asset) nilai VIF $=1.267$

3) Variabel Efisiensi Modal Kerja nilai VIF $=1.110$.

Dari nilai - nilai VIF tersebut di atas menunjukan nilai VIF tidak mendekati 5, sehingga tidak terjadi multikolinieritas.

c. Uji Heteroskedastisitas

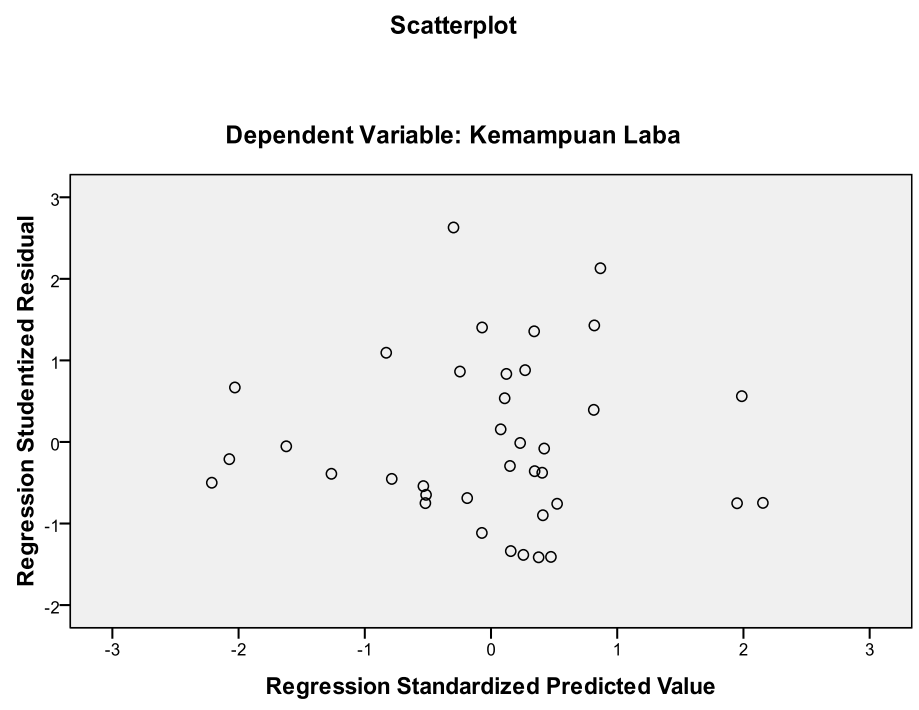

Gambar 3. Grafik Scatterplot

Dari grafik di atas, titik-titik yang ada tidak membentuk pola tertentu serta menyebar di atas dan di bawah angka 0 pada sumbu Y, maka maka asumsi heteroskedastisitas tidak terjadi, dan model regresi layak untuk digunakan. 
2. Uji Korelasi dan Regresi

a. Uji Simultan (Uji F)

Tabel 4. F Hitung

ANOVA $^{\mathrm{b}}$

\begin{tabular}{|c|c|c|c|c|c|c|}
\hline & & Sum of Squares & df & Mean Square & $\mathbf{F}$ & Sig. \\
\hline 1 & $\begin{array}{l}\text { Regression } \\
\text { Residual } \\
\text { Total }\end{array}$ & $\begin{array}{r}462.885 \\
3358.451 \\
3821.336\end{array}$ & $\begin{array}{r}3 \\
33 \\
36\end{array}$ & $\begin{array}{c}154.295 \\
101.771\end{array}$ & 5.516 & $.019^{a}$ \\
\hline
\end{tabular}

Menurut tabel di atas diketahui besar $\mathrm{F}_{\text {hitung }}=5.516$, lebih besar dari $\mathrm{F}_{\text {tabel }}=2.892$, karena $\mathrm{F}_{\text {hitung }}>\mathrm{F}_{\text {tabel }}$ maka Ho ditolak. Sedangkan uji $\mathrm{F}$ yang dilakukan dengan melihat nilai probabilitas signifikansinya menghasilkan nilai probabilitas $=0,019<\alpha=0,05$ maka Ho ditolak, yang berarti variabel Likuiditas (Current Ratio), Tingkat Hutang (Debt to Total Asset), Efisiensi Modal Kerja secara bersama-sama berpengaruh signifikan terhadap kemampuan laba.

b. Uji Parsial (Uji t)

Tabel 5. Hasil Uji Parsial Variabel $\mathrm{X}_{1}, \mathrm{X}_{2}$, dan $\mathrm{X}_{3}$ terhadap $\mathrm{Y}$

\begin{tabular}{|l|c|c|c|}
\hline \multicolumn{1}{|c|}{ Variabel } & thitung $_{1}$ & $\mathbf{t}_{\text {tabel }}$ & Sig \\
\hline Current Ratio & 3.357 & 2.342 & .018 \\
\hline Debt to Total Asset & 2.940 & 2.342 & .024 \\
\hline Efisiensi Modal Kerja & 2.121 & 2.342 & .194 \\
\hline
\end{tabular}

Sumber : Hasil pengolahan data

Dari tabel di atas, nilai thitung Likuiditas $\left(\right.$ Current Ratio) $=3.357$, nilai thitung $_{\text {Tingkat Hutang }}$ (Debt to Total Asset $)=2.940$, nilai thitung Efisiensi Modal Kerja $=2.121$. Untuk mencari $\mathrm{t}_{\text {tabel}}, \mathrm{df}=\mathrm{n}-\mathrm{k}-1=37-1-1=35$ dengan signifikansi $(\alpha)$ 0,025 dan uji dua sisi diperoleh $\mathrm{t}_{\text {tabel }}=2.342$. Terlihat bahwa nilai thitung untuk variabel Likuiditas (Current Ratio) dan Tingkat Hutang (Debt to Total Asset) lebih besar dari tabel dengan signifikansi lebih kecil dari 0,025, maka Ho ditolak atau Ha diterima. Hal ini berarti bahwa variabel Likuiditas (Current Ratio) dan Tingkat Hutang (Debt to Total Asset) memiliki pengaruh yang signifikan terhadap variabel kemampuan laba. Sedangkan untuk Efisiensi Modal Kerja nilai

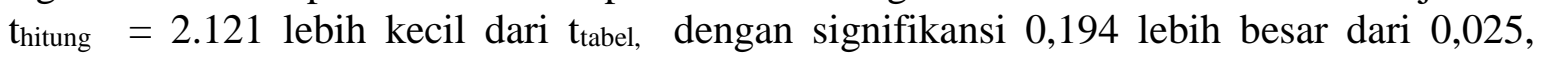
sehingga Efisiensi Modal Kerja tidak berpengaruh signifikan terhadap kemampuan laba. 
c. Persamaan regresi

Tabel 6. Koefisien Regresi

\begin{tabular}{|c|c|c|c|c|c|}
\hline \multirow[b]{2}{*}{ Model } & \multicolumn{2}{|c|}{$\begin{array}{l}\text { Unstandardized } \\
\text { Coefficients }\end{array}$} & \multirow{2}{*}{\begin{tabular}{c|}
$\begin{array}{l}\text { Standardized } \\
\text { Coefficients }\end{array}$ \\
Beta \\
\end{tabular}} & \multirow[b]{2}{*}{$t$} & \multirow[b]{2}{*}{ Sig. } \\
\hline & B & $\begin{array}{l}\text { Std. } \\
\text { Error }\end{array}$ & & & \\
\hline -(Constant) & 87.735 & 6.090 & & $\begin{array}{r}14.40 \\
6\end{array}$ & .000 \\
\hline Current Ratio & 0.01608 & .000 & .238 & 3.357 & .018 \\
\hline Debt to Total Asset & 5.965 & 6.346 & .173 & 2.940 & .024 \\
\hline Efisiensi Modal Kerja & .040 & .330 & .021 & 2.121 & .194 \\
\hline
\end{tabular}

Sumber : Hasil pengolahan SPSS

Persamaan regresi yang bisa dibentuk dari pengaruh antara variabel Likuiditas (Current Ratio), Tingkat Hutang (Debt to Total Asset), Efisiensi Modal Kerja secara bersama - sama terhadap variabel Kemampuan Laba adalah sebagai berikut :

$\hat{\mathrm{Y}}=87.735+0.01608 \mathrm{X}_{1}+5.965 \mathrm{X}_{2}+0.040 \mathrm{X}_{3}$ atau

Kemampuan Laba $=87.735+0.01608$ Current Ratio +5.965 Debt to Total Asset + 0.040 Efisiensi Modal Kerja

Angka koefisien regresi 0.01608 menyatakan bahwa setiap penambahan satu nilai variabel Likuiditas (Current Ratio) akan menaikkan Kemampuan Laba (Y) sebesar 0.01608 kali. Angka koefisien regresi 5.965 menyatakan bahwa setiap penambahan satu nilai variabel Tingkat Hutang (Debt to Total Asset) akan menaikkan Kemampuan Laba (Y) sebesar 5.965 kali, koefisien regresi 0.040 menyatakan bahwa setiap penambahan satu nilai variabel Efisiensi Modal Kerja akan meningkatkan Kemampuan Laba (Y) sebesar 0.040 kali.

\section{d. Koefisien Determinasi}

Tabel 7. Koefisien Adjusted R Square Variabel Bebas secara Simultan Terhadap Variabel Terikat

\begin{tabular}{|c|c|c|c|c|c|}
\hline \multicolumn{6}{|c|}{ Model Summary } \\
\hline Model & $\mathbf{R}$ & R Square & $\begin{array}{l}\text { Adjusted R } \\
\text { Square }\end{array}$ & $\begin{array}{l}\text { Std. Error of the } \\
\text { Estimate }\end{array}$ & $\begin{array}{l}\text { Durbin- } \\
\text { Watson }\end{array}$ \\
\hline 1 & $.648^{\mathrm{a}}$ & .419 & .441 & 7.08817 & 1.403 \\
\hline
\end{tabular}


Uji regresi untuk mengetahui besarnya kemampuan variabel-variabel bebas dalam menerangkan variasi variabel tidak bebasnya, dapat dilihat dari nilai koefisien Adjusted $R$ Square. Besarnya nilai Adjusted R Square Likuiditas (Current Ratio), Tingkat Hutang (Debt to Total Asset), Efisiensi Modal Kerja terhadap Kemampuan Laba (Y) = 0,441 atau 44,1 $\%$, artinya variabel Likuiditas (Current Ratio), Tingkat Hutang (Debt to Total Asset), Efisiensi Modal Kerja mampu menerangkan variasi variabel Kemampuan Laba (Y) sebesar $44,1 \%$, dan sisanya 55,9\% dipengaruhi oleh faktor lain di luar model.

Variable Likuiditas (Current Ratio) berpengaruh signifikan terhadap Kemampuan Laba. Hal ini sesuai dengan penelitian yang pernah dilakukan oleh Khalaf Taani (2012), yang menyimpulkan bahwa kebijakan manajemen modal kerja berpengaruh signifikan terhadap laba bersih. Demikian juga penelitian yang dilakukan oleh Asih (2009) dan Noor \& Lestari (2012), bahwa secara parsial likuiditas berpengaruh signifikan terhadap profitabilitas pada perusahaan industri barang konsumsi yang terdaftar di BEI. Hasil penelitian ini juga sesuai dengan teori bahwa perusahaan yang mampu memenuhi kewajiban keuangannya tepat pada waktunya berarti perusahaan tersebut dalam keadaan "likuid" artinya perusahaan tersebut memiliki alat pembayaran ataupun aktiva lancar yang lebih besar daripada hutang lancar. Perusahaan yang hanya mencari keuntungan tanpa memperhatikan likuiditas pada akhirnya perusahaan tersebut akan mengalami "illikuid" apabila sewaktu-waktu ada tagihan. Menurut Van Horn $(2011,224)$ “ jika perusahaan mengetahui dengan pasti permintaan penjualan dimasa depan, penagihan piutang dan jadwal produksinya, maka perusahaan dapat mengatur jadwal maturitas hutangnya sehingga berhubungan dengan jadwal arus kas bersih di masa yang akan datang, akibatnya laba akan maksimal, dikarenakan tidak ada kebutuhan untuk menyimpan aktiva lancar ataupun pendanaan jangka panjang diluar kebutuhan"

Tingkat Utang (Debt to Total Asset) berpengaruh signifikan terhadap Kemampuan Laba. Hal ini sesuai dengan penelitian yang pernah dilakukan oleh Maria Rasheed Awan (2014) yang menyatakan bahwa Debt to asset mempunyai pengaruh yang signifikan terhadap return on asset, demikian juga penelitian yang sama juga dilakukan oleh Khalaf Taani (2012), bahwa financial leverage memiliki hubungan yang signifikan terhadap laba bersih. Hasil penelitian ini juga sejalan dengan penelitian yang telah dilakukan oleh Nugraeni (2005) dan Raheman (2009), solvabilitas berpengaruh signifikan terhadap profitabilitas.

Variable efisiensi modal kerja berpengaruh signifikan terhadap Kemampuan Laba. Hal ini sesuai dengan penelitian yang pernah dilakukan oleh Khalaf Taani (2012), menunjukkan hasil bahwa kebijakan manajemen modal kerja memiliki pengaruh positif terhadap laba bersih perusahaan. Demikian juga penelitian yang telah dilakukan oleh Nugraeni (2005) dan Raheman (2009) bahwa efisiensi modal kerja berpengaruh signifikan terhadap profitabilitas. Hasil penelitian ini juga sesuai dengan teori bahwa modal kerja dapat terus berputar sejalan dengan aktivitas operasi perusahaan sehari-hari, oleh karena itu diperlukan adanya suatu pengendalian terhadap sumber dan penggunaan modal kerja yang dibuat dalam bentuk suatu laporan perubahan modal kerja. Pengawasan terhadap sumber dan penggunaan modal kerja merupakan hal yang penting bagi perusahaan yang ingin mempertahankan kontinuitas perusahaan. 


\section{KESIMPULAN DAN SARAN}

Kesimpulan dari penelitian ini adalah :

a. Berdasarkan uji t dari ketiga variabel independen yang dianalisis :

1). Dari besarnya $t$ hitung dapat diketahui variabel yang paling berpengaruh terhadap Kemampuan Laba adalah variabel Likuiditas (Current Ratio), diikuti variabel Tingkat hutang (Debt to Total Asset) dan terakhir adalah Efisiensi Modal Kerja.

2). Variabel Likuiditas (Current Ratio), mempunyai pengaruh yang signifikan terhadap Kemampuan Laba.

3). Variabel Tingkat Hutang (Debt to Total Asset) mempunyai pengaruh yang signifikan terhadap Kemampuan Laba.

4). Variabel Efisiensi Modal Kerja mempunyai pengaruh yang tidak signifikan terhadap Kemampuan Laba.

b. Berdasarkan uji F dari ketiga variabel independen yang dianalisis yaitu Likuiditas (Current Ratio), Tingkat Hutang (Debt to Total Asset), dan Efisiensi Modal Kerja, secara bersama sama mempunyai pengaruh yang signifikan terhadap Kemampuan Laba.

Sehubungan dengan hasil penelitian ini maka saran yang dapat diajukan adalah sebagai berikut :

a. Pihak manajemen Puskesmas harus menjaga likuiditas (Current Ratio) secara baik, karena apabila likuiditasnya terlalu tinggi, maka kemampuan labanya menurun. Selain itu, manajemen Puskesmas juga harus memperhatikan tingkat hutang (Debt to Total Asset), karena jika Puskesmas membiayai dengan hutang dari pihak luar maka akan menurunkan kemampuan labanya. Pihak manajemen Puskesmas hendaknya mampu mempertahankan modal kerjanya secara efisien. Karena apabila modal kerja dalam Puskesmas menunjukkan angka yang tinggi/stabil, maka kemampuan laba akan meningkat. Untuk itu manajemen Puskesmas harus menjaga likuiditas, tingkat hutang dan modal kerja secara baik dan efisien agar Puskesmas mampu menghasilkan laba yang diharapkan.

b. Bagi penelitian selanjutnya diharapkan dapat memperbanyak jumlah sampel, dan menambahkan faktor-faktor lain yang mempengaruhi kemampuan laba Puskesmas. Jumlah sampel penelitian yang lebih banyak diharapkan mampu memberikan gambaran yang lebih jelas pengaruh-pengaruh faktor-faktor Likuiditas (Current Ratio), Tingkat Hutang (Debt to Total Asset), dan Efisiensi Modal Kerja terhadap Kemampuan Laba.

\section{REFERENSI}

Ahmad, Alim Bachri. (2013), "Pengaruh Dimensi Kualitas Pelayanan Puskesmas S. Parman Banjarmasin Terhadap Kepuasan Pasien Dalam Memperoleh Pelayanan Kesehatan." Jurnal Wawasan Manajemen Vol.1No.1. pp. 65-90.

Asih, H. D. (2009), Pengaruh Likuiditas, Solvabilitas dan Perputaran Modal Kerja Terhadap Profitabilitas pada Perusahaan Real Estate dan Property yang Terdaftar di Bursa Efek Indonesia, Unnes Press, Semarang.

Djarwanto, (2011), Pokok-pokok Analisa Laporan Keuangan, Edisi Kedua, BPFE, Yogyakarta.

Guna, Welvin I., and Arleen Herawaty. (2010), "Pengaruh Mekanisme Good Corporate Governance, Independensi Auditor, Kualitas Audit dan Faktor Lainnya Terhadap Manajemen Laba." Jurnal bisnis dan akuntansi Vol12. No.1 pp. 53-68. 
Horne, Van dan Wachowicz. (2013), Prinsip-prinsip Manajemen Keuangan. Edisi Indonesia. Penerbit Salemba Empat, Jakarta.

Khalaf Taani (2012), Impact of Working Capital Management Policy and Financial Leverage on Financial Performance: Empirical evidence from Amman Stock Exchange - listed companies, International Journal of Management Sciences and Business Research, , Vol. 1, Issue 8.

Maria Rasheed Awan (2014), Impact of liquidity, leverage, inflation on firm profitability an empirical analysis of food sector of Pakistan, IOSR Journal of Business and Management, Volume 16, Issue 1. Ver. VII.

Noor, Aris Setia dan Lestari, Berta (2012), Analisis Pengaruh Efisiensi Modal Kerja, Likuiditas, dan Solvabilitas terhadap Profitabilitas (Studi Kasus Pada Industri Barang Konsumsi di Bursa Efek Indonesia), Universitas Islam Kalimantan Muhammad Arsyad Al Banjary, Banjarmasin.

Nugraeni, S. (2005), Analisis Pengaruh Efisiensi Modal Kerja, Likuiditas, dan Solvabilitas Terhadap Profitabilitas Pada Perusahaan Property And Real Estate Yang Go Publik di Bursa Efek Jakarta. Unnes Press, Semarang.

Putri, Nesya Yulita, (2009). "Pengaruh Non Performing Loan Dan Likuiditas Terhadap Kinerja Keuangan Perusahaan Pada Bank Bumn (Periode 2004-2008)."

Raheman, A., Afza, T., Qayyum, A \& Bodla, M. A. (2009), Working Capital Management and Corporate Performance of Manufacturing Sector in Pakistan. International Research Journal of Finance and Economics. Issue 47, pp: 151-163.

Riyanto, Bambang (2013), Dasar-Dasar Pembelanjaan Perusahaan, Edisi keempat, Yayasan Penerbit Gajah Mada, Yogyakarta.

Wibowo, Agus, and Sri Wartini. (2012), "Efisiensi Modal Kerja, Likuiditas dan Leverage Terhadap Profitabilitas Pada Perusahaan Manufaktur di BEI." Jurnal Dinamika Manajemen 3.1

Widiyanti, Marlina, and Samadi W. Bakar. (2014): "Pengaruh Working Capital Turnover, Cash Turnover, Inventory Turnover Dan Current Ratio Terhadap Profitabilitas (ROA) Perusahaan Property Dan Real Estate Yang Terdaftar Di BEI." Jurnal Manajemen Dan Bisnis Sriwijaya 12.2 pp. 111-126. 